\title{
Удосконалення часткової методики оптимізації маршруту перевезення матеріальних засобів
}

\author{
Юрій Ганненко * А \\ А Національний університет оборони України імені Івана Черняховського, пр-кт Повітрофлотський, 28, м. Київ, 03049, Україна
}

Received: October 012, 2020 | Revised: October 26, 2020 | Accepted: October 31, 2020

DOI: $10.33445 /$ sds.2020.10.5.11

\begin{abstract}
Анотація
У статті на основі аналізу системи перевезення матеріальних засобів Збройних Сил України проведено дослідження стосовно удосконалення часткової методики оптимізації маршруту перевезення матеріальних засобів Збройних Сил України.

На сьогодні існуючі методики носять частковий характер та не враховують нові чинники врахування раціональності та оптимізації маршруту руху, які в сучасних умовах значно впливають на ефективність системи перевезення матеріальних засобів.

Одним з основних завдань системи перевезення $€$ своєчасність, повнота перевезення та мінімізація витрат, пов'язаних з доведенням матеріального потоку від первинного джерела (виробника, постачальника) до кінцевого споживача (підрозділу).

у дослідженні щодо оптимізації маршрутів перевезення матеріальних засобів визначається найкоротший шлях, що веде з джерела забезпечення до пункту призначення в зв'язній мережі при заданих відстанях, асоційованих з кожним ребром мережі.

Дослідження полягає у визначенні оптимального маршруту проходження по мережі між пунктами по пов'язаних з ними дорогах, з мінімальною загальною довжиною пройденого шляху із застосуванням методів мережевого планування.
\end{abstract}

Ключові слова: система перевезення, матеріальні засоби, мережеве планування, логістичне забезпечення, ресурси.

\section{Постановка проблеми}

Збройна агресія Російської Федерації проти України стала довгостроковим чинником впливу на українську політичну, економічну, соціальну та військову реальність $[1,2]$. Внаслідок дій Російської Федерації було деформовано систему перевезення матеріальних засобів (далі - МЗ), яка на той час вже була в стані розформування та недофінансування.

В ході проведення антитерористичної операції на сході України в ЗС України виникла проблема 3 нераціональним та неефективним перевезенням M3 i транспортуванням озброєння та військової техніки. Так, мали місце випадки, коли із Заходу на Схід відправляли невеликий вантаж з різних військових частин, різними автомобілями одночасно, що було неефективним, не раціональним та економічно необґрунтованим рішенням.

Досвід останніх локальних війн та збройних конфліктів [3] свідчить про наявність тенденції зростання обсягу перевезення МЗ в операціях (бойових діях) на 10-15\% за кожні 8-10 років, що $\epsilon$ дуже актуальним питанням та потребує наукового дослідження для його вирішення.

Створення нової системи перевезення М3, із впровадженням логістики в ЗС України, замість неефективної системи тилового та технічного забезпечення, стало поштовхом для написання даної статті.

\footnotetext{
* Corresponding author: ад'юнкт кафедри тилового забезпечення, e-mail: yugans@ukr.net
} 


\section{Аналіз останніх досліджень та публікацій}

Аналіз останніх наукових досліджень і публікацій свідчить про те, що дослідженню підвищення ефективності системи перевезення матеріальних засобів присвячена низка робіт попередників, зокрема Кивлюка В. С., Трегубенка С. С., Шевченка Р. М., Клонцака М. М. та інших [3, 4], які в свій час зробили вагомий внесок у розвиток теорії військової науки.

\section{Постановка завдання}

Одним із шляхів підвищення ефективності системи перевезення МЗ Збройних Сил України $€$ оптимальний вибір маршрутів перевезення з врахуванням стану доріг та районів знаходження незаконно-збройних формувань. Але питанням, що стосуються оптимізації маршрутів перевезення М3 в теорії і практиці приділено недостатньо уваги.

Для вирішення наукового завдання $\epsilon$ необхідність у в удосконаленні часткової методики оптимізації маршруту перевезення M3.

\section{Виклад основного матеріалу}

Перевезення МЗ $\epsilon$ одним 3 головних завдань логістичного забезпечення i здійснюється 3 метою створення запасів матеріальних засобів, поповнення їх витрат і втрат у військах, військових частинах і установах логістичного забезпечення [5]. Перевезення дуже важливе і складне завдання логістичного забезпечення військ в сучасних операціях, одна з визначальних умов високої бойової готовності і здатності військових частин (підрозділів) вести активні і тривалі бойові дії з рішучими цілями без оперативних пауз.

Роль перевезення М3 в логістичному забезпеченні визначається безпосередньою залежністю ходу і результату операцій (бойових дій) від своєчасної доставки військам (силам) продовольства, озброєння та військової техніки, речового майна, майна КEC, майна оперативного забезпечення, пальномастильних матеріалів та спеціальних рідин, фортифікаційних та будівельних матеріалів, боєприпасів та інших видів матеріальних засобів [6].

Для здійснення перевезення матеріальних засобів у військові частини (підрозділи), окремі батальйони матеріального забезпечення, об'єднані центри забезпечення, бази (склади) розгортається і функціонує система перевезення М3.

Система перевезення матеріальних засобів - це сукупність органів військового управління, сил i засобів, які використовуються для перевезення та транспортні комунікації.

Для оптимізації маршруту перевезення М3 застосовано математичний метод, при якому використовується графічне моделювання планованого комплексу виконуваних робіт, що відображає їх логічну послідовність, існуючу взаємозв'язок і плановану тривалість.

Оптимізація перевезення МЗ здійснюється за настурними критеріями :

мінімізація часу для перевезення матеріальних засобів при заданій вартості або нормам забезпечення;

мінімізація вартості перевезення матеріальних засобів при заданому часовому показнику.

3 метою оптимізації маршруту перевезення M3 запропоновано використовувати методи мережевого планування [7], які дозволяють здійснити кількісні оцінки маршрутів перевезення МЗ від об'єднаних центрів забезпечення до окремих батальйонів матеріального забезпечення, і на цій основі вибрати найбільш раціональні шляхи їх виконання.

Для оптимізації маршруту перевезення матеріальних засобів мережного графіка застосовано наступні методи:

метод критичного шляху, який дозволяє розрахувати можливі календарні графіки виконання перевезення МЗ на основі описаної 
логічної структури мережі і оцінок тривалості виконання кожної роботи, визначити критичний шлях перевезення.

метод оцінки й аналізу, це спосіб аналізу завдань, необхідних для виконання перевезення М3, особливо аналізу часу, який потрібен для виконання кожної окремої задачі, а також визначення мінімально необхідного часу для виконання всього циклу перевезення M3 [8].

Для складання мережевого графіку визначаються та кількісно описується весь комплекс перевезення М3.

Характерними задачами мережевого планування [9] при перевезенні M3 $\epsilon$ визначення:

мінімального часу $T_{\min }$ виконання комплексу робіт;

переліку маршрутів, що впливають на резервів часу ;

мінімізація вартості перевезення при заданому часі та визначеному об'єкті забезпечення.

Передумови моделювання перевезення М3 включають аналіз перевезення з розбивкою його на незалежні маршрути і специфікацію для них відносин передування. Маршрути зображені графічно у вигляді стрілок (спрямованих ребер), а міста (пункти) задаються кільцями (вершинами) мережі.

Мережевий графік подається у вигляді навантаженого орієнтованого графа, душ якого являють маршрути перевезення, а довжина дуг визначається їх тривалістю. Приклад мережевого графіка, що зображує комплекс робіт 3 десяти ймовірних маршрутів перевезення, зображений на мал. 1.

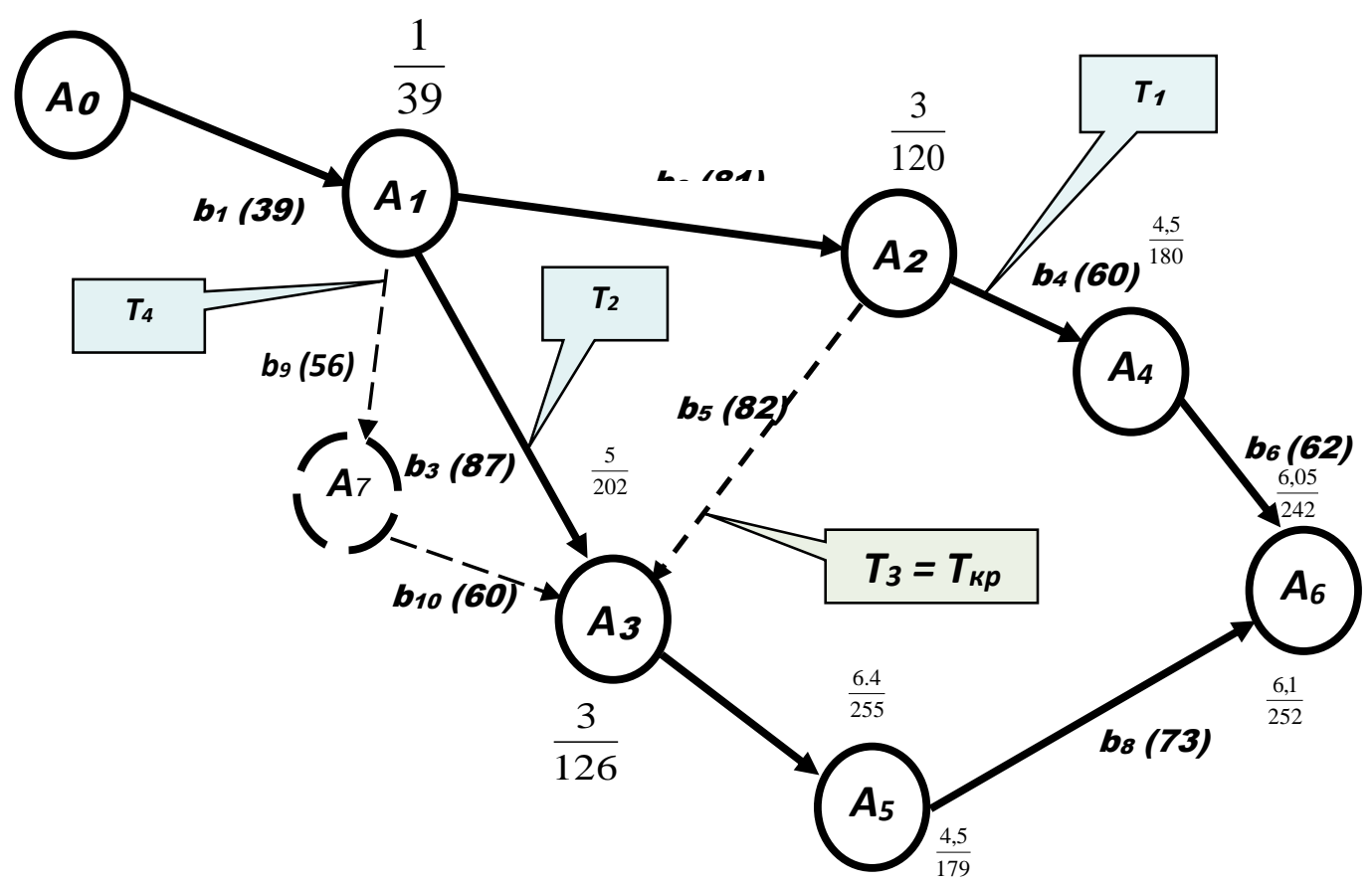

Малюнок 1 - Мережевий графік перевезення М3

Мережевий графік перевезення МЗ $\epsilon$ графічним зображенням (мал. 1) всієї послідовності перевезення та завершуючих їх подій, що відображає система перевезення М3.

Для використання графа [10] необхідно виконати його упорядкування. Під час вирішення цього завдання використовуються такі поняття, як вершина-попередник та вершина-послідовник. Якщо з вершини А0, існує шлях до вершини A1, то першу буде попередником, а друга - послідовником.

Визначення найкоротшого шляху має на меті відшукання найкоротшого маршруту 3 вихідного пункту - об'єднаного центру забезпечення в місця призначення, через мережу альтернативних маршрутів. 
Ця модель може визначити маршрут колони з одного пункту в інший по мережі ймовірних доріг, що мінімізує загальну відстань, час та вартість перевезення МЗ.

Для вирішення найкоротшого шляху необхідно визначити найбільш ранній час $t_{i}^{p}$ за формулою

$$
t_{j}^{\mathrm{p}}=\max _{\mathrm{i}}\left\{t_{\mathrm{i}}^{\mathrm{p}}+t_{i j}\right\},
$$

де $t_{\mathrm{i}}^{\mathrm{p}}$ - найбільш ранній час здійснення події;

$i$ - номери всіх подій.

Найпізніший час здійснення події, тобто це такий час, який не призводить до затримки виконання завершальної події, розраховується за формулою

$$
t_{j}^{n}=\min _{\mathrm{i}}\left\{t_{\mathrm{i}}^{n}+t_{i j}\right\},
$$

де $t_{\mathrm{i}}^{n}$ - найпізніший час здійснення події.

Резерв часу буде найбільший час, на який може бути затримана поява події, без збільшення часу $T$ виконання всього комплексу перевезення М3:

$$
R_{\mathrm{i}}=t_{i}^{n}-t_{i}^{p}
$$

Повним резервом часу на маршруті перевезення буде час, на який може буде продовжене виконання цієї роботи без збільшення часу $T$ :

$$
R_{\mathrm{i}}=t_{i}^{n}-t_{i}^{p}-t_{i j}
$$

Шлях в мережевому графіку (мал. 1) буде вся послідовність маршрутів (стрілок), що зв'язує між собою кілька подій (маршрутів) та визначається за формулою

$$
t_{i}=\sum \quad b_{i} \geq T_{\min }
$$

Відповідно до мережевого графіку, показаного на мал. 1, встановлено, що маршрути, які утворюють критичний шлях, резервів часу не мають і визначають мінімальний час виконання всього комплексу перевезення.

Наявність резерву часу виконання маршрутів, свідчить про можливість перерозподілу ресурсів з метою скорочення часу, що складають критичний час.

Для оцінювання маршрутів перевезення М3 в таблицях 1, 2 показані результати щодо визначення структури, часу та протяжності маршруту перевезення М3.

\section{Таблиця 1 - Структурно-часова таблиця перевезення М3}

\begin{tabular}{|c|c|c|c|c|c|}
\hline № 3/п & Вуз. поч. / кін. & $\begin{array}{c}\text { На які ЕР } \\
\text { спирається }\end{array}$ & $\begin{array}{c}\text { Найменування } \\
\text { маршрутів } \\
\text { перевезення }\end{array}$ & $\begin{array}{c}\text { Дальність } \\
\text { виконання ЕP }\end{array}$ & Час ЕР (мін) \\
\hline 1 & $a_{01}$ & & $b_{1}$ & 39 & $(60)$ \\
\hline 2 & $a_{12}$ & $a_{01}$ & $b_{2}$ & 81 & $(120)$ \\
\hline 3 & $a_{13}$ & $a_{01}, a_{73}$ & $b_{3}$ & 87 & $(130)$ \\
\hline 4 & $a_{23}$ & $a_{12}$ & $b_{4}$ & 82 & $(123)$ \\
\hline 5 & $a_{24}$ & $a_{12}$ & $b_{5}$ & 60 & $(90)$ \\
\hline 6 & $a_{35}$ & $a_{13,} a_{23}, a_{73}$ & $b_{6}$ & 53 & $(80)$ \\
\hline 7 & $a_{46}$ & $a_{24}$ & $b_{7}$ & 62 & $(93)$ \\
\hline 8 & $a_{56}$ & $a_{35}$ & $b_{8}$ & 73 & $(110)$ \\
\hline 9 & $a_{17}$ & $a_{01}$ & $b_{9}$ & 56 & $(84)$ \\
\hline 10 & $a_{73}$ & $a_{17}$ & $b_{10}$ & 60 & $(90)$ \\
\hline
\end{tabular}

Аналізуючи розрахований мережевий графік на мал. 1, можна встановити, що роботи, які утворюють критичний шлях, резервів часу не мають і визначають мінімальний час виконання перевезення.

Наявність резерву часу виконання перевезення свідчить про можливість перерозподілу ресурсів з метою скорочення часу виконання робіт, що складають критичний шлях. В цьому i полягає удосконалення часткової методики оптимізації маршруту перевезення. 


\section{Таблиця 2 - Розрахунок оптимального маршруту перевезення М3}

\begin{tabular}{|c|c|c|c|c|c|c|c|c|c|c|c|c|c|c|c|c|}
\hline & $b_{1}$ & $b_{2}$ & $b_{3}$ & $b_{4}$ & $b_{5}$ & $b_{6}$ & $b_{7}$ & $b_{8}$ & $b_{9}$ & $b_{10}$ & I & II & III & IV & V & VI \\
\hline$b_{1}$ & - & - & - & - & - & - & - & - & - & - & 0 & 0 & 0 & 0 & 0 & 0 \\
\hline$b_{2}$ & 1 & - & - & - & - & - & - & - & - & - & 1 & 0 & 0 & 0 & 0 & 0 \\
\hline$b_{3}$ & 1 & - & - & - & - & - & - & - & - & - & 1 & 0 & 0 & 0 & 0 & 0 \\
\hline$b_{4}$ & - & 1 & 1 & - & - & - & - & - & - & - & 2 & 2 & 0 & 0 & 0 & 0 \\
\hline$b_{5}$ & - & 1 & - & - & - & - & - & - & - & - & 1 & 1 & 0 & 0 & 0 & 0 \\
\hline$b_{6}$ & - & - & 1 & 1 & - & - & - & - & - & 1 & 3 & 3 & 2 & 1 & 1 & 1 \\
\hline$b_{7}$ & - & - & - & - & 1 & - & - & - & - & - & 1 & 1 & 1 & 1 & 0 & 0 \\
\hline$b_{8}$ & - & - & - & - & - & 1 & - & - & - & - & 1 & 1 & 1 & 1 & 1 & 0 \\
\hline$b_{9}$ & 1 & - & 1 & - & - & - & - & - & - & - & 2 & 1 & 0 & 0 & 0 & 0 \\
\hline$b_{10}$ & - & - & - & - & - & - & - & - & 1 & - & 1 & 1 & 1 & 1 & 1 & 0 \\
\hline
\end{tabular}

\section{Висновки}

Мережеві моделі відіграють велику роль при плануванні перевезення матеріальних засобів та планування заходів бойової підготовки. Такі моделі відносно легко описуються в мережній формі і легко сприймаються керівним складом завдяки зоровому ефекту.

Таким чином, застосування мережевого планування під час перевезення матеріальних запасів $€$ важливим елементом під підготовки та ведення бойових дій.

Перспективи подальших досліджень вбачаються в застосуванні чисельних показників в комплексній методиці оцінювання ефективності функціонування системи перевезення матеріальних засобів Збройних Сил України.

\section{Список використаних джерел}

1. Воєнна доктрина України: Указ Президента України від 24.09.2015 р. № 555/2015). К.: АПУ, 2015. URL: https://zakon.rada.gov.ua/ laws/show/555/2015.

2. Стратегія національної безпеки України: Указ Президента України від 14.09.2020 р. №392/2020. К.: АПУ, 2020.

3. Кивлюк В.С., Ганненко Ю.О. Удосконалення системи забезпечення матеріальними ресурсами Збройних сил України: Журнал наукових праць "Social development \& Security". 4, 2. Київ, 2018. С. 49-58. DOI: 10.5281/ZENODO.1231404.

4. Клонцак М. Я., Кивлюк В. С., Лоза В. М., Шевченко В. В. Вироблення єдиних поглядів щодо створення сучасної державної системи логістики Збройних Сил України :збір. наук. праць військового інституту київського національного університету ім. Тараса Шевченка. Вип. 51. 2016. C. 100-109. URL: http://nbuv.gov.ua/ UJRN/Znpviknu_2016_51_15

5. Про затвердження Основних положень логістичного забезпечення 3С України: наказ Міністерства оборони України від 11.10.2016 p. № 522.

6. Доктрина об'єднана логістика: наказ Генерального штабу ЗС України від 30.09.2020 URL: https://elib.nuou.org.ua/ katalog/doktrina-ob\%D1\%94dnana-log\%D1 \% 96stika.html.

7. Воєнна наука, як фундаментальна основа наукових досліджень і підготовки фахівців вищих навчальних закладів Збройних Сил України: підручник. ч. І. НУОУ. Київ, 2002. $559 \mathrm{c.}$

8. Основи моделювання бойових дій військ. Підручник. Київ : НАОУ, 2005. 481 с.

9. Матвейчук Ф. А. Справочник по исследованию операцій: Воениздат. М., 1979. 368 c.

10. Фрэнк Харари. Теория графов, М.,1973, $300 \mathrm{c}$.

11. Tkach, M. (2020). Patterns of development of national power: historical experience of the world states. Political Science and Security Studies Journal, 1(1), 40-48. DOI: $10.5281 /$ zenodo. 4256820 


\title{
Совершенствование частичной методики оптимизации маршрута перевозки материальных средств
}

\author{
Юрий Ганненко * А \\ *Corresponding author: адьюнкт кафедры тылового обеспечения, e-mail: yugans@ukr.net

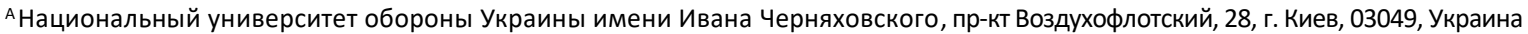

\begin{abstract}
Аннотация
В статье на основе анализа системы перевозки материальных средств Вооруженных Сил Украины проведено исследование по усовершенствованию частичной методики оптимизации маршрута перевозки материальных средств Вооруженных Сил Украины.

На сегодня существующие методики носят частичный характер и не учитывают новые факторы учета рациональности и оптимизации маршрута движения, которые в современных условиях имеют значительное влияние на эффективность системы перевозки материальных средств.

Одной из основных задач системы перевозки является своевременность, полнота перевозки и минимизация затрат, связанных с доведением материального потока от первичного источника (производителя, поставщика) к конечному потребителю (подразделения).

В исследовании по оптимизации маршрутов перевозки материальных средств определяется кратчайший путь, ведущий из источника обеспечения в пункт назначения в связной сети при заданных расстояниях, ассоциированных с каждым ребром сети.

Исследования заключается в определении оптимального маршрута движения по сети между пунктами по связанных с ними дорогах, с минимальной общей длиной пройденного пути с применением методов сетевого планирования.
\end{abstract}

Ключевые слова: система перевозки, материальные средства, сетевое планирование, логистическое обеспечение, ресурсы.

\section{Improving the partial method of optimizing the route of the material resources transportation}

\author{
lurii Hannenko * A \\ "Corresponding author: PhD student, e-mail: yugans@ukr.net \\ A National Defence University of Ukraine named after Ivan Cherniakhovskyi, 28, Povitroflotskyi Ave, Kyiv, 03049, Ukraine
}

\begin{abstract}
In the article on the basis of the analysis of the system of transportation of material means of the Armed Forces of Ukraine the research concerning improvement of a partial technique of optimization of a route of transportation of material means of the Armed Forces of Ukraine is carried out.

Today, the existing methods are partial in nature and do not take into account the new factors of rationality and optimization of the route, which in modern conditions significantly affect the efficiency of the system of transportation of material resources.

One of the main tasks of the transportation system is the timeliness, completeness of transportation and minimization of costs associated with bringing the material flow from the primary source (manufacturer, supplier) to the final consumer (unit).

The study on the optimization of material transportation routes identifies the shortest path leading from the source of supply to the destination in the connected network at specified distances associated with each edge of the network.
\end{abstract}


The study is to determine the optimal route for the passage of the network between points on the associated roads, with a minimum total length of the distance traveled using network planning methods.

Keywords: transportation system, material resources, network planning, logistics, resources.

\section{References}

1. Voyenna doktryna Ukrayiny: Ukaz Prezydenta Ukrayiny vid 24.09.2015 r. № 555/2015). K.: APU, 2015. Available from: https://zakon. rada.gov.ua/laws/show/555/2015.

2. Stratehiya natsional'noyi bezpeky Ukrayiny: Ukaz Prezydenta Ukrayiny vid 14.09.2020 r. №392/2020. Kyiv: APU, 2020.

3. Kyvlyuk V. S., Hannenko YU. O. Udoskonalennya systemy zabezpechennya material'nymy resursamy Zbroynykh syl Ukrayiny: Zhurnal naukovykh prats' "Social development \& Security". 4, 2. Kyiv, 2018. S. 49-58. DOI: 10.5281/ZENODO.1231404.

4. Klontsak M. Y., Kyvlyuk V. S., Loza V. M., Shevchenko V.V. Vyroblennya yedynykh pohlyadiv shchodo stvorennya suchasnoyi derzhavnoyi systemy lohistyky Zbroynykh Syl Ukrayiny: zbir. nauk. prats' viys'kovoho instytutu kyyivs'koho natsional'noho universytetu imeni Tarasa Shevchenka. Vyp. 51. 2016. S. 100-109. Available from: http://nbuv.gov.ua/UJRN/Znpviknu_2016_5 1_15.

5. Pro zatverdzhennya Osnovnykh polozhen' lohistychnoho zabezpechennya ZS Ukrayiny: nakaz Ministerstva oborony Ukrayiny vid 11.10.2016 r. № 522.

6. Doktryna ob'yednana lohistyka: nakaz Heneral'noho shtabu ZS Ukrayiny vid 30.09.2020. Available from: https://elib. nuou.org.ua/katalog/doktrinaob\%D1\%94dnana-log\%D1\%96stika.html.

7. Voyenna nauka, yak fundamental'na osnova naukovykh doslidzhen' i pidhotovky fakhivtsiv vyshchykh navchal'nykh zakladiv Zbroynykh Syl Ukrayiny: pidruchnyk. ch.I. NUOU. Kyyiv, 2002. inv.176824. 559 s.

8. Osnovy modelyuvannya boyovykh diy viys'k. Pidruchnyk. Kyiv: NAOU, 2005. 481 s.

9. Matveychuk F. A. Spravochnyk po yssledovanyyu operatsiy: Voenyzdat. Moscow, 1979. $368 \mathrm{~s}$.

10. Frénk Kharary. Teoryya hrafov, Moscow, 1973, $300 \mathrm{~s}$.

11. Tkach, M. (2020). Patterns of development of national power: historical experience of the world states. Political Science and Security Studies Journal, 1(1), 40-48. DOI: 10.5281 /zenodo. 4256820 